\title{
Analisis Dinamik Model Predator-Prey dengan Faktor Kanibalisme Pada Predator
}

\author{
Dwi Safitri'1, Heni Widayani2², Usman Pagalay ${ }^{3}$ \\ Program Studi Matematika, Fakultas Sains dan Teknologi, Universitas Islam Negeri Maulana Malik Ibrahim \\ Malang, Indonesia
}

Email: dwisafitri8363@gmail.com, heniwidayani@mat.uin-malang.ac.id*, usmanpagalay@yahoo.co.id

\begin{abstract}
ABSTRAK
Kajian dinamika populasi predator-prey di suatu ekosistem dengan adanya kanibalisme pada predator dilakukan pada penelitian ini. Ketika ada kanibalisme di tingkat predator dikhawatirkan populasi predator itu akan menurun atau terjadi kepunahan, sehingga populasi prey menjadi tidak terkontrol dan akan terjadi ketidakseimbangan ekosistem. Oleh karena itu, pada penelitian ini dibangunlah model matematika predatorprey dengan faktor kanibalisme pada predator berbentuk sistem persamaan diferensial biasa non linier dengan tiga persamaan untuk mengetahui dinamika model tersebut. Kemudian di analisis dengan mencari kestabilan dari masing-masing titik kesetimbangan dan diilustrasikan dengan simulasi numerik. Pada model predatorprey tersebut ditemukan dua titik kesetimbangan yang memiliki kemungkinan stabil yaitu titik kesetimbangan ketika tidak ada prey $\left(E_{0}\right)$ dan titik kesetimbangan ketika kedua spesies eksis di ekosistem tersebut . Hasil sensitivitas analisis menunjukkan bahwa sifat kestabilan lokal dari titik $E_{0}$ maupun $E^{*}$ bergantung pada parameter kanibalisme yakni $\beta$ dan $\varepsilon$. Lebih lanjut, untuk titik $E^{*}$ telah dibuktikan sifat kestabilan global menggunakan fungsi lyapunov. Hasil simulasi numerik mengilustrasikan hasil analisa yang sudah diperoleh, sehingga ditemukan kemungkinan terjadinya limit cycles yang menandakan adanya bifurkasi hopf. Hasil analisis dinamik model predator-prey dengan kanibalisme pada predator, maka dapat diketahui perilaku dari model tersebut yang dapat digunakan agar suatu populasi tidak terancam punah.
\end{abstract}

Kata kunci: model predator-prey; kanibalisme; stabilitas lokal; limit cycles; bifurkasi hopf.

\begin{abstract}
The study of predator-prey population dynamics in an ecosystem in the presence of cannibalism in predators is carried out in this study. When there is cannibalism at the predator level, it is feared that the predator population will decrease or extinction will occur. Consequently the prey population becomes uncontrolled and there will be an ecosystem imbalance. In this study, a predator-prey mathematical model was built with the cannibalism factor in predators in the form of a system of non-linear ordinary differential equations with three equations to determine the dynamics of the model. Then it is analyzed by looking for the stability of each equilibrium point and illustrated by numerical simulation. In the predator-prey model, there are two equilibrium points that have a stable possibility, namely the equilibrium point when there is no prey $\left(E_{0}\right)$ and the equilibrium point when both species exist in the ecosystem. The results of the sensitivity analysis show that the local stability properties of points $E_{0}$ and $E^{*}$ depend on the cannibalism parameters, namely $\beta$ and $\varepsilon$. Furthermore, for the point $E^{*}$, global stability properties have been demonstrated using the lyapunov function. The results of the numerical simulation illustrate the results of the analysis that have been obtained, so that the possibility of limit cycles is found which indicates the existence of a hopf bifurcation. The results of the dynamic analysis of the predator-prey model with cannibalism on predators, it can be seen the behavior of the model that can be used so that a population is not threatened with extinction.
\end{abstract}


Keywords: predator-prey model; cannibalism; local stability; limit cycles; hopf bifurcation.

\section{PENDAHULUAN}

Model matematika sering membahas masalah-masalah fenomena alam yang terjadi di antara makhluk hidup. Salah satunya adalah masalah di ekosistem makhluk hidup. Semua makhluk hidup melakukan interaksi untuk bertahan hidup, baik sesama spesies maupun berbeda spesies. Interaksi saling memangsa antara satu spesies dengan spesies lainnya merupakan bentuk interaksi demi mempertahankan kelangsungan hidup. Dalam matematika model interaksi tersebut diperkenalkan oleh Vito Volterra dan Alfred J. Lotka pada tahun 1980 disebut sebagai model Lotka-Volterra atau model Predator-Prey [1]. Populasi pada ekosistem mengalami peningkatan dan penurunan seiring perkembangan zaman. Faktor-faktor yang memicu pertumbuhan populasi antara lain kematian, kelahiran, dan lingkungan. Sifat-sifat perilaku pada predator salah satunya yaitu Predasi intraspesifik disebut sebagai kanibalisme, yaitu proses membunuh dan kemudian memakan individu dari spesies yang sama. Pada permasalahan ekosistem, maka bidang matematika berperan dalam hal tersebut. Salah satu persamaan dalam bidang matematika yaitu persamaan diferensial [2], yang terdiri dari persamaan diferensial linier [3] dan non-linier[4]. Penelitian sebelumnya telah menganalisis model predator-prey antara lain kanibalisme prey yang dapat mengubah dinamika model predator-prey tipe Holling-Tanner [5], efek kanibalisme secara eksplisit pada model predator-prey yang terstruktur oleh tiga usia dalam satu spesies[6], model predator-prey dengan kanibalisme dan adanya penyakit di kedua populasi[7], serta model predator-prey dengan kanibalisme dengan adanya penundaan[8].

Pada [9], Zhang mengonstruksi model matematika predator-prey dengan kanibalisme.

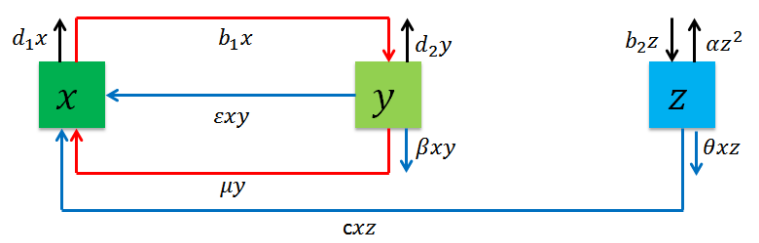

Sehingga membentuk model predator-prey dengan kanibalisme dari sistem tersebut yaitu sistem persamaan diferensial non-linier [10] sebagai berikut.

$$
\begin{aligned}
& \frac{d x}{d t}=-d_{1} x+\mu y+\varepsilon x y+c x z \\
& \frac{d y}{d t}=b_{1} x-\mu y-d_{2} y-\beta x y \\
& \frac{d z}{d t}=\left(b_{2}-\alpha z-\theta x\right) z
\end{aligned}
$$

Dari model tersebut, $d_{1}$ adalah angka kematian alami dari predator dewasa, $d_{2}$ adalah angka kematian alami dari predator remaja, $b_{1}$ yaitu angka kelahiran predator dewasa, $b_{2}$ yaitu tingkat pertumbuhan bersih prey, $\mu$ menunjukkan tingkat pematangan predator remaja, $\alpha$ menunjukkan Menggambarkan persaingan antar spesies prey (kepadatan populasi prey), $\theta$ merupakan Tingkat penangkapan predator dewasa ke prey, $c$ merupakan Peningkatan laju predator dewasa melalui memakan prey, $\beta$ merupakan Tingkat penangkapan predator 
dewasa ke predator remaja, dan $\varepsilon$ merupakan Peningkatan laju predator dewasa melalui memakan predator remaja.

Penyelesaian dari model predator-prey dengan kanibalisme pada predator yaitu dengan melinierkan model tersebut, kemudian didapatkan matriks Jacobi serta nilai eigen dari masing-masing titik kesetimbangan yang didapatkan. Analisis kestabilan dari titik kesetimbangan [11] ketika $\alpha=0$ dengan meninjau beberapa sifat kestabilan sistem linier. Kestabilan titik kesetimbangan juga dianalisis menggunakan kriteria Routh-Hurwitz untuk kestabilan lokal [12] dan fungsi lyapunov [13]. Fungsi lyapunov memiliki definisi dalam menentukan titik kestabilan yang bersifat stabil global [14]. Sehubungan dengan stabilitas lokal maka terdapat limit cycles yang memungkinkan terjadi bifurkasi hopf [15].

\section{METODE}

\section{Langkah-langkah yang dilakukan dari penelitian ini:}

1. Analisis dinamik model predator-prey tanpa kanibalisme
a. Menentukan titik kesetimbangan
b. Melinierkan model predator-prey tanpa kanibalisme
c. Menentukan jenis kestabilan dari setiap titik kesetimbangan

2. Analisis dinamik model predator-prey dengan kanibalisme
a. Menentukan titik kesetimbangan
b. Melinierkan model predator-prey dengan kanibalisme
c. Menentukan jenis kestabilan dari setiap titik kesetimbangan
d. Menyimulasikan solusi sistem numerik menggunakan metode Runge-Kutta orde 4

\section{HASIL DAN PEMBAHASAN}

Pada analisa dinamik berikutnya maka untuk memudahkan prosesnya, akan dilakukan penskalaan variabel dengan memisalkan

$$
x=\frac{d_{1} \bar{x}}{\theta}, \quad y=\frac{d_{1}^{2} \bar{y}}{\theta \mu}, \quad z=\frac{d_{1} \bar{z}}{c}, \quad t=\frac{\bar{t}}{d_{1}},
$$

dari pemisalan tersebut, dengan menetapkan bahwa $x>0, y>0$ dan $z \geq 0$. Sehingga didapatkan

$\bar{\varepsilon}=\frac{d_{1} \varepsilon}{\theta \mu}, \quad \bar{b}_{1}=\frac{b_{1} \mu}{d_{1}^{2}}, \quad \bar{\beta}=\frac{\beta}{\theta}, \quad \bar{\mu}=\frac{\mu}{d_{1}}, \quad \bar{d}_{2}=\frac{d_{2}}{d_{1}}, \quad \bar{\sigma}=\bar{\mu}+\bar{d}_{2}, \quad \bar{b}_{2}=\frac{b_{2}}{d_{1}}$.

Dengan demikian didapatkan laju predator dewasa, predator remaja dan prey sebagai berikut

$$
\begin{aligned}
& \frac{d \bar{x}}{d \bar{t}}=-\bar{x}+\bar{y}+\bar{\varepsilon} \bar{x} \bar{y} \\
& +\bar{x} \bar{z} \\
& \frac{d \bar{y}}{d \bar{t}}=\bar{b}_{1} \bar{x}-\bar{\sigma} \bar{y}-\bar{\beta} \bar{x} \bar{y} \\
& \frac{d \bar{z}}{d \bar{t}}=\left(\bar{b}_{2}-\bar{x}\right) \bar{z}
\end{aligned}
$$

Untuk mempermudah penjelasan selanjutnya, maka simbol dari $\bar{x}, \bar{y}, \bar{z}, \bar{\varepsilon}, \bar{b}, \bar{\sigma}, \bar{\beta}$ dan $\bar{b}_{2}$ masing-masing diubah ke bentuk simbol $x, y, z, \varepsilon, b_{1}, \sigma, \beta$ dan $b_{2}$ sehingga diperoleh

$$
\frac{d x}{d t}=-x+y+\varepsilon x y+x z
$$




$$
\begin{aligned}
& \frac{d y}{d t}=b_{1} x-\sigma y-\beta x y \\
& \frac{d z}{d t}=\left(b_{2}-x\right) z
\end{aligned}
$$

Menurut arti parameter dalam model (1), parameter $\varepsilon$ dan $\beta$ dalam sistem (4) adalah non negatif dan parameter lainnya positif. Secara khusus, $\beta=\varepsilon=0$ menunjukkan bahwa tidak ada kanibalisme dalam populasi pemangsa. Untuk sistem (4), jelas bahwa $\left.\frac{d x}{d t}\right|_{x=0}=$ $y>0$ untuk $y>0,\left.\frac{d y}{d t}\right|_{y=0}=b_{1} x>0$ untuk $x>0$, dan bahwa bidang $x-y$ (yaitu $z=0$ ) adalah invarian positif. Oleh karena itu, himpunan $\Omega_{0}=\{(x, y, z): x>0, y>0, z \geq 0\}$ adalah invarian positif dari (4).

\section{Analisis Model Predator-Prey (4) Tanpa Kanibalisme}

Pada bagian ini, mempertimbangkan kestabilan titik kesetimbangan pada sistem (3.4) dengan tidak adanya kanibalisme. Hasil yang diperoleh di sini sangat membantu dalam memahami efek kanibalisme dalam kasus ini.

Ketika tanpa adanya kanibalisme, yaitu $\beta=\varepsilon=0$, maka sistem (4) menjadi

$$
\begin{gathered}
\frac{d x}{d t}=-x+y+x z \\
\frac{d y}{d t}=b_{1} x-\sigma y \\
\frac{d z}{d t}=\left(b_{2}-x\right) z
\end{gathered}
$$

Ketika tidak ada mangsa $(z=0)$, maka sistem (5) menjadi

$$
\begin{aligned}
& \frac{d x}{d t}=-x+y \\
& \frac{d y}{d t}=b_{1} x-\sigma y
\end{aligned}
$$

Ketika $\sigma<b_{1}$, titik kesetimbangan dari sistem (6) merupakan titik asal yaitu titik dimana $(x=0, y=0)$ yang merupakan pelana(Saddle) karena nilai eigen $\lambda_{1}>0$ dan $\lambda_{2}<0$. Ketika $\sigma>b_{1}$ memiliki titik $E_{0}(x=0, y=0, z=0)$ yang memiliki nilai eigen yang positif $b_{2}$ sehingga titik kesetimbangan $E_{0}$ selalu tidak stabil, serta memiliki titik $E^{*}\left(x^{*}=b_{2}, y^{*}=\right.$ $\left.\frac{b_{1} b_{2}}{\sigma}, z^{*}=1-\frac{b_{1}}{\sigma}\right)$ maka sistem (5) dapat dituliskan

$$
\begin{aligned}
& \frac{d x}{d t}=x\left[\left(\frac{y}{x}-\frac{y^{*}}{x^{*}}\right)+\left(z-z^{*}\right)\right] \\
& \frac{d y}{d t}=b_{1} y\left(\frac{x}{y}-\frac{x^{*}}{y^{*}}\right) \\
& \frac{d z}{d t}=-z\left(x-x^{*}\right)
\end{aligned}
$$

Kemudian turunan dari fungsi $V_{1}$ sepanjang solusi sistem (5) yaitu

$$
\frac{d V_{1}}{d t}=y^{*}\left(2-\frac{x y^{*}}{x^{*} y}-\frac{x^{*} y}{x y^{*}}\right)
$$

memenuhi bahwa $\frac{d V_{1}}{d t} \leq 0$ untuk $x>0$ dan $y>0$, serta $\frac{d V_{1}}{d t}=0$ ketika $x=x^{*}$ dan $y=y^{*}$. Maka ekuilibrium positif $E^{*}$ dari sistem (5) stabil asimtotik global dalam $\Omega_{0}$ jika eksis.

Singkatnya, kita telah sampai pada deskripsi lengkap tentang dinamika (5).

Teorema 1. Untuk sistem (5), dua pernyataan berikut berlaku. 
(i) Jika $\sigma<b_{1}$, maka terdapat titik asal $O$ yang merupakan pelana (saddle)

(ii) Jika $\sigma>b_{1}$, maka titik $E_{0}$ eksis tetapi tidak stabil , dan $E^{*}$ stabil secara global asimtotik di $\Omega_{0}$.

\section{Analisis Dinamik Model Predator-Prey (4) dengan Kanibalisme}

\subsection{Eksistensi dan Sifat Kestabilan Titik Kesetimbangan}

Selain titik asal $O(0,0,0)$, sistem (4) memiliki titik kesetimbangan $E_{0}=\left(x_{0}=\right.$ $\left.\frac{\sigma-b_{1}}{b_{1} \varepsilon-\beta}, y_{0}=\frac{\sigma-b_{1}}{\sigma \varepsilon-\beta}, z_{0}=0\right)$ ketika $\frac{\beta}{\varepsilon}<b_{1}<\sigma$ atau $\sigma<b_{1}<\frac{\beta}{\varepsilon}$ dan ada titik kesetimbangan positif $E^{*}\left(x^{*}=b_{2}, y^{*}=\frac{b_{1} b_{2}}{\sigma+\beta b_{2}}, z^{*}=1-\frac{b_{1}\left(1+\varepsilon b_{2}\right)}{\sigma+\beta b_{2}}\right)$ ketika $b_{1}<\frac{\sigma+\beta b_{2}}{1+\varepsilon b_{2}}$ atau ekuivalen ketika $\varepsilon<\varepsilon_{1}(\beta):=\frac{\sigma+\beta b_{2}-b_{1}}{b_{1} b_{2}}$.

$$
E^{*}\left(x^{*}=b_{2}, y^{*}=\frac{b_{1} b_{2}}{\sigma+\beta b_{2}}, z^{*}=1-\frac{b_{1}\left(1+\varepsilon b_{2}\right)}{\sigma+\beta b_{2}}\right)
$$

Sehubungan dengan stabilitas lokal maka kesetimbangan (4) memiliki hasil sebagai berikut.

Teorema 2. Pernyataan berikut tentang stabilitas lokal kesetimbangan dari (4).

(i) Ekuilibrium $O$ selalu tidak stabil

(ii) Batas ekuilibrium $E_{0}$ stabil secara lokal asimtotik jika $\varepsilon_{1}(\beta)<b_{1}<\frac{\beta}{\varepsilon}$ dan tidak stabil jika $\sigma<b_{1}<\varepsilon_{1}(\beta)$ atau $\frac{\beta}{\varepsilon}<b_{1}<\sigma$.

(iii) Ekuilibrium positif $E^{*}$ tidak stabil jika $\sigma>b_{1}$ dan $\varepsilon_{2}(\beta)<\varepsilon<\varepsilon_{1}(\beta)$, sedangkan stabil secara lokal asimtotik jika salah satu dari dua kondisi, $(C 1): \sigma \leq b_{1}$ dan $\varepsilon<\varepsilon_{1}(\beta)$, dan (C2): $\sigma>b_{1}$ dan $\varepsilon<\varepsilon_{2}(\beta)$, dimana

\section{Pembuktian.}

$$
\varepsilon_{2}(\beta)=\frac{1}{\sigma}\left[\beta+\frac{\left(\sigma-b_{1}\right)\left(\sigma+\beta b_{2}\right)}{\sigma\left(\sigma+\beta b_{2}\right)^{2}+b_{1}\left(\sigma+b_{2}\right)}\right] .
$$

(i) Matriks Jacobi dari sistem (4) pada titik asal $O$ yaitu

$$
J(O)=\left(\begin{array}{ccc}
-1 & 1 & 0 \\
b_{1} & -\sigma & 0 \\
0 & 0 & b_{2}
\end{array}\right)
$$

memiliki nilai eigen positif $b_{2}$ sehingga titik kesetimbangan $O$ selalu tidak stabil.

(ii) Matriks Jacobi dari sistem (4) pada titik $E_{0}$ yaitu

$$
J\left(E_{0}\right)=\left(\begin{array}{ccc}
-1+\varepsilon y_{0} & 1+\varepsilon x_{0} & x_{0} \\
b_{1}-\beta y_{0} & -\left(\sigma+\beta x_{0}\right) & 0 \\
0 & 0 & b_{2}-x_{0}
\end{array}\right)
$$

Perhatikan bahwa $x_{0}$ dan $y_{0}$ memenuhi $-1+\varepsilon y_{0}=-\frac{y_{0}}{x_{0}}, 1+\varepsilon x_{0}=\frac{x_{0}}{y_{0}}, b_{1}-\beta y_{0}=\frac{\sigma y_{0}}{x_{0}}$, dan $\sigma+\beta x_{0}=-\frac{b_{1} x_{0}}{y_{0}}$. Kita bisa menulis ulang $J\left(E_{0}\right)$ sebagai

$$
J\left(E_{0}\right)=\left(\begin{array}{ccc}
-\frac{y_{0}}{x_{0}} & \frac{x_{0}}{y_{0}} & x_{0} \\
\frac{\sigma y_{0}}{x_{0}} & -\frac{b_{1} x_{0}}{y_{0}} & 0 \\
0 & 0 & b_{2}-x_{0}
\end{array}\right)
$$


Dari matriks Jacobi tersebut maka nilai eigen dari $E_{0}$ yaitu $b_{2}-x_{0}$ dan dua nilai eigen yang lain dari persamaan kuadrat $\lambda^{2}+\lambda\left(\frac{y_{0}}{x_{0}}+\frac{b_{1} x_{0}}{y_{0}}\right)+\left(b_{1}-\sigma\right)=0$. Sehingga, ketika $E_{0}$ ada maka stabil secara lokal asimtotik jika dan hanya jika $b_{1}>\sigma$ dan $b_{2}<x_{0}$.

Menurut syarat keberadaan dari $E_{0}, b_{1}>\sigma$ memenuhi bahwa $b_{1}<\frac{\beta}{\varepsilon}$. Maka $b_{2}<$ $x_{0}=\frac{b_{1}-\sigma}{\beta-b_{1} \varepsilon}$ ekivalen dengan $b_{1}>\varepsilon_{1}(\beta)$ ketika $E_{0}$ ada. Perhatikan bahwa $\sigma<\frac{\beta}{\varepsilon}$ memenuhi bahwa $\sigma<\varepsilon_{1}(\beta)<\frac{\beta}{\varepsilon}$. Hal ini, dikombinasikan dengan kondisi keberadaan $E_{0}$, membuktikan bahwa $E_{0}$ stabil secara lokal asimtotik jika $\varepsilon_{1}(\beta)<b_{1}<\frac{\beta}{\varepsilon}$ dan tidak stabil jika $\sigma<b_{1}<$ $\varepsilon_{1}(\beta)$ atau $\frac{\beta}{\varepsilon}<b_{1}<\sigma$.

(iii) Matriks Jacobi dari sistem (4) pada titik $E^{*}$ yaitu

$$
J\left(E^{*}\right)=\left(\begin{array}{ccc}
-1+\varepsilon y^{*}+z^{*} & 1+\varepsilon x^{*} & x^{*} \\
b_{1}-\beta y^{*} & -\left(\sigma+\beta x^{*}\right) & 0 \\
-z^{*} & 0 & 0
\end{array}\right)
$$

Sebagai $x^{*}, y^{*}$ dan $z^{*}$ memenuhi $-1+\varepsilon y^{*}+z^{*}=-\frac{y^{*}}{x^{*}}, 1+\varepsilon x^{*}=\frac{x^{*}\left(1-z^{*}\right)}{y^{*}}, b_{1}-\beta y^{*}=\frac{\sigma y^{*}}{x^{*}}$ dan $-\left(\sigma+\beta x^{*}\right)=-\frac{b_{1} x^{*}}{y^{*}}, J\left(E^{*}\right)$ dapat ditulis ulang sebagai

$$
J\left(E^{*}\right)=\left(\begin{array}{ccc}
-\frac{y^{*}}{x^{*}} & \frac{x^{*}\left(1-z^{*}\right)}{y^{*}} & x^{*} \\
\frac{\sigma y^{*}}{x^{*}} & -\frac{b_{1} x^{*}}{y^{*}} & 0 \\
-z^{*} & 0 & 0
\end{array}\right)
$$

Sehingga persamaan karakteristik dari $J\left(E^{*}\right)$ adalah

$0=\left|\lambda I-J\left(E^{*}\right)\right|=\lambda^{3}+a_{1} \lambda^{2}+a_{2} \lambda+a_{3}$

di mana

$$
a_{1}=\frac{y^{*}}{x^{*}}+\frac{b_{1} x^{*}}{y^{*}}, \quad a_{2}=z^{*}\left(\sigma+x^{*}\right)-\left(\sigma-b_{1}\right), \quad a_{3}=\frac{b_{1} x^{* 2} z^{*}}{y^{*}} .
$$

Perhitungan selanjutnya mengikuti Kriteria Hurwitz, yaitu didapatkan

$$
a_{1} a_{2}-a_{3}=\frac{\left(b_{1} \sigma x^{* 2}+\sigma y^{* 2}+x^{*} y^{* 2}\right) z^{*}+\left(b_{1}-\sigma\right)\left(b_{1} x^{* 2}+y^{* 2}\right)}{x^{*} y^{*}}
$$

Selanjutnya, substitusikan (3.7) ke (3.8) maka menghasilkan

$$
\begin{aligned}
a_{1} a_{2}-a_{3}= & \frac{b_{1} b_{2}}{\left(\sigma+\beta b_{2}\right)^{2}}\left\{\left(\sigma+\beta b_{2}\right)\left[\beta\left(\sigma+\beta b_{2}\right)\right]+b_{1}(\beta-1)\right. \\
& \left.-\varepsilon\left[\sigma\left(\sigma+\beta b_{2}\right)^{2}+b_{1}\left(\sigma+b_{2}\right)\right]\right\}
\end{aligned}
$$

Perhatikan bahwa

$$
\varepsilon_{1}(\beta)-\varepsilon_{2}(\beta)=\frac{\left(\sigma-b_{1}\right)\left(\sigma+\beta b_{2}\right)\left[\left(\sigma+\beta b_{2}\right)^{2}+b_{1}\right]}{b_{1} b_{2}\left[\sigma\left(\sigma+\beta b_{2}\right)^{2}+b_{1}\left(\sigma+b_{2}\right)\right]}
$$

jika $\sigma \leq b_{1}$ Maka $\varepsilon_{1}(\beta) \leq \varepsilon_{2}(\beta)$ dan jika $\sigma>b_{1}$ maka $\varepsilon_{1}(\beta)>\varepsilon_{2}(\beta)$. Oleh karena itu, ketika $E^{*}$ ada, jika $\sigma \leq b_{1}$ atau $\sigma>b_{1}$ dan $\left\langle\varepsilon_{2}(\beta)\right.$ maka $a_{1} a_{2}-a_{3}>0$, sedangkan jika $\sigma>$ $b_{1}$ dan $\varepsilon_{2}(\beta)<\varepsilon<\varepsilon_{1}(\beta)$ maka $a_{1} a_{2}-a_{3}<0$. Selanjutnya dengan menggunakan Kriteria Hurwitz, kondisi stabil secara lokal asimtotik pada sistem (4) adalah ketika $a_{1} a_{2}-a_{3}>0$.

Hasil selanjutnya berkaitan dengan stabilitas global dari titik ekuilibrium $E^{*}$.

Teorema 3. Pernyataan berikut tentang sistem (4)

Ketika $E^{*}$ eksis, maka akan stabil secara global jika $\beta \geq \varepsilon \sigma$.

\section{Pembuktian.}

Demikian pula, sehubungan dengan $E^{*}$, sistem (4) dapat ditulis ulang sebagai 


$$
\begin{aligned}
& \frac{d x}{d t}=x\left[\left(\frac{y}{x}-\frac{y^{*}}{x^{*}}\right)+\varepsilon\left(y-y^{*}\right)+\left(z-z^{*}\right)\right] \\
& \frac{d y}{d t}=y\left[b_{1}\left(\frac{x}{y}-\frac{x^{*}}{y^{*}}\right)-\beta\left(x-x^{*}\right)\right] \\
& \frac{d z}{d t}=-z\left(x-x^{*}\right)
\end{aligned}
$$

Menetapkan fungsi sebagai berikut

$$
V_{2}=\left(x-x^{*}-x^{*} \ln \frac{x}{x^{*}}\right)+n \frac{x^{*}}{y^{*}}\left(y-y^{*}-y^{*} \ln \frac{y}{y^{*}}\right)+\left(z-z^{*}-z^{*} \ln \frac{z}{z^{*}}\right)
$$

di mana $n=\frac{b_{1}\left(\sigma-\sigma \varepsilon b_{2}+2 \beta b_{2}\right)}{\sigma^{2}\left(\sigma+\beta b_{2}\right)}$. Kemudian turunan dari $V_{2}$ sepanjang solusi dari sistem (4) yaitu

$$
\begin{aligned}
\frac{d V_{2}}{d t} & =\left(x-x^{*}\right)\left[\left(\frac{y}{x}-\frac{y^{*}}{x^{*}}\right)+\varepsilon\left(y-y^{*}\right)\right]+n \frac{x^{*}}{y^{*}}\left(y-y^{*}\right)\left[b_{1}\left(\frac{x}{y}-\frac{x^{*}}{y^{*}}\right)-\beta\left(x-x^{*}\right)\right] \\
& =-\frac{x y}{x^{*}}\left[\left(1-\frac{x^{*}}{x}\right)^{2}+\frac{n b_{1} x^{* 2}}{y^{* 2}}\left(1-\frac{y^{*}}{y}\right)^{2}-\left(\varepsilon x^{*}+1+\frac{n b_{1} x^{* 2}}{y^{* 2}}-\frac{n \beta x^{* 2}}{y^{*}}\right)\left(1-\frac{x^{*}}{x}\right)\left(1-\frac{y^{*}}{y}\right)\right]
\end{aligned}
$$

Perhatikan bahwa

$$
\varepsilon x^{*}+1=\frac{x^{*}\left(1-z^{*}\right)}{y^{*}} \quad \text { dan } \quad \beta x^{*}=\frac{b_{1} x^{*}-\sigma y^{*}}{y^{*}}
$$

Maka

Mengikuti keterangan tersebut maka

$$
\varepsilon x^{*}+1+\frac{n b_{1} x^{* 2}}{y^{* 2}}-\frac{n \beta x^{* 2}}{y^{*}}=\frac{x^{*}\left(n \sigma+1-z^{*}\right)}{y^{*}}
$$

$$
\begin{aligned}
\frac{d V_{2}}{d t} & =-\frac{x y}{x^{*}}\left[\left(1-\frac{x^{*}}{x}\right)^{2}+\frac{n b_{1} x^{* 2}}{y^{* 2}}\left(1-\frac{y^{*}}{y}\right)^{2}-\frac{x^{*}\left(n \sigma+1-z^{*}\right)}{y^{*}}\left(1-\frac{x^{*}}{x}\right)\left(1-\frac{y^{*}}{y}\right)\right] \\
& =-\frac{x y}{x^{*}}\left\{\left[\left(1-\frac{x^{*}}{x}\right)-\frac{\left(n \sigma+1-z^{*}\right) x^{*}}{2 y^{*}}\left(1-\frac{y^{*}}{y}\right)\right]^{2}+\left[n b_{1}-\frac{\left(n \sigma+1-z^{*}\right)^{2}}{4}\right] \frac{x^{* 2}}{y^{* 2}}\left(1-\frac{y^{*}}{y}\right)^{2}\right\}
\end{aligned}
$$

Substitusikan $n=\frac{b_{1}\left(\sigma-\sigma \varepsilon b_{2}+2 \beta b_{2}\right)}{\sigma^{2}\left(\sigma+\beta b_{2}\right)}$ ke persamaan tersebut sehingga

$$
\frac{d V_{2}}{d t}=-\frac{x y}{x^{*}}\left\{\left[\left(1-\frac{x^{*}}{x}\right)-\frac{b_{1} x^{*}}{\sigma y^{*}}\left(1-\frac{y^{*}}{y}\right)\right]^{2}+\frac{b_{1}^{2} b_{2}(\beta-\varepsilon \sigma)}{\sigma^{2}\left(\sigma+\beta b_{2}\right)} \frac{x^{* 2}}{y^{* 2}}\left(1-\frac{y^{*}}{y}\right)^{2}\right\}
$$

Jadi ketika $\beta \geq \varepsilon \sigma$ maka $\frac{d V_{2}}{d t}<0$, sedangkan ketika $x=x^{*}$ dan $y=y^{*}$ maka $\frac{d V_{2}}{d t}=0$. Kemudian dapat dilihat bahwa ketika $\beta \geq \varepsilon \sigma$, himpunan invariant terbesar dari (4) dalam himpunan $\left\{(x, y, z) \in \Omega_{0}: \frac{d V_{2}}{d t}=0\right\}$ adalah singleton $\left\{E^{*}\right\}$. Oleh karena itu, $E^{*}$ stabil secara global jika $\beta \geq \varepsilon \sigma$ oleh prinsip Invarian La Salle.

Pada kesetimbangan positif $E^{*}$, kondisi keberadaan $E^{*}$ adalah $\varepsilon<\varepsilon_{1}(\beta)$. Kondisi dalam Teorema 3 untuk stabilitas global adalah $\beta \geq \varepsilon \sigma$ sedangkan Teorema 2 menunjukkan bahwa kondisi stabilitas lokalnya adalah (C1): $\sigma \leq b_{1}$ dan $\varepsilon<\varepsilon_{1}(\beta)$, atau (C2): $\sigma>b_{1}$ dan $\varepsilon<\varepsilon_{2}(\beta)$.

\subsection{Sensitivitas Titik Kesetimbangan Terhadap $\beta$ dan $\varepsilon$}

Untuk memahami lebih jelas kondisi stabilitas lokal $E_{0}$ dan $E^{*}$ dan sensitivitas pada parameter $\beta$ dan $\varepsilon$, maka diilustrasikan secara geometris dengan menggunakan daerah yang sesuai di bidang $\beta-\varepsilon$. Nilai parameter untuk gambar 1 pada (a) $\sigma<b_{1}$ yaitu $\sigma=1, b_{1}=$ $6, b_{2}=25, \beta=[0,1]$; pada (b) $\sigma>b_{1}$ yaitu $\sigma=6, b_{1}=0.1, b_{2}=25, \beta=[0,1]$. 


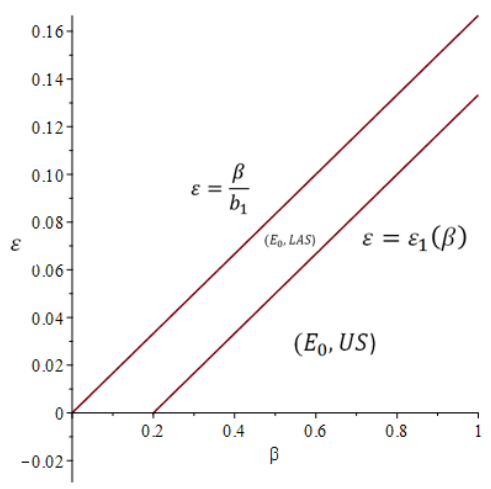

(a)

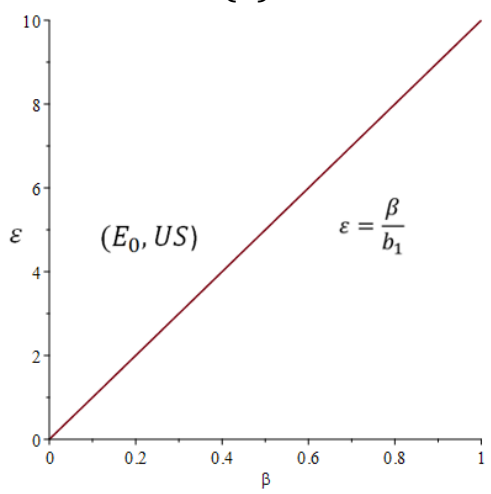

(b)

Gambar 1. Wilayah Keberadaan dan Stabilitas Lokal $E_{0}$ di Bidang $\beta-\varepsilon$ : (a) $\sigma<b_{1}$; (b) $\sigma>$ $b_{1}$

Teorema 2 dan Gambar 1 menunjukkan bahwa jika $\sigma>b_{1}, E_{0}$ pasti tidak stabil asalkan ada. Berdasarkan stabilitas lokal $E_{0}$ dan keberadaan $E^{*}$, dengan kondisi $\sigma<b_{1}, E_{0}$ pasti tidak stabil selama $E^{*}$ ada. Nilai parameter untuk gambar 2 pada (a) $\sigma<b_{1}$ yaitu $\sigma=$ $1, b_{1}=6, b_{2}=25, \beta=[0,1]$; pada (b) $\sigma=b_{1}$ yaitu $\sigma=2, b_{1}=2, b_{2}=25, \beta=[0,1]$.



(a) 


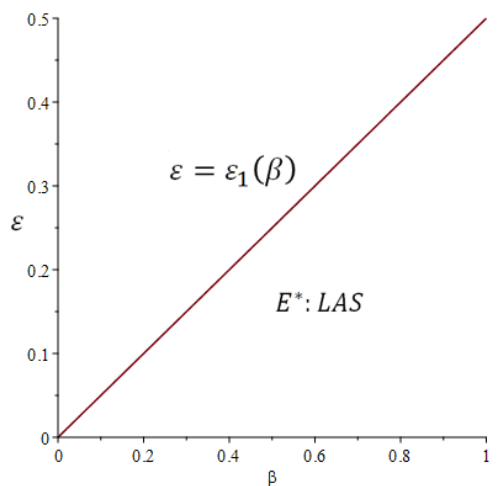

(b)

Gambar 2. Wilayah Keberadaan dan Stabilitas Lokal $E^{*}$ di Bidang $\beta-\varepsilon$ : (a) $\sigma<b_{1}$; (b) $\sigma=$ $b_{1}$

Dalam Gambar 2 dan 3, enam kemungkinan kasus ditunjukkan sehubungan dengan keberadaan dan stabilitas $E^{*}$. Perhatikan bahwa jika $\sigma<b_{1}$ maka $\varepsilon_{1}(\beta)<\varepsilon_{2}(\beta)$ dan jika $\sigma=b_{1}$ maka $\varepsilon_{1}(\beta)=\varepsilon_{2}(\beta)$. Kemudian, untuk kasus pada Gambar 2 (a) dan (b), yang sesuai dengan $\sigma \leq b_{1}, E^{*}$ pasti stabil secara lokal asimtotik selama eksis menurut Teorema 2 .

Untuk nilai parameter pada gambar 3 ketika $\sigma>b_{1}$, (c) $\sigma=6, b_{1}=1, b_{2}=10, \beta=$ $[0,1]$; (d) $\sigma=6, b_{1}=0.1, b_{2}=120, \beta=[0,1]$; (e) $\sigma=1.4, b_{1}=0.1, b_{2}=35, \beta=[0,1]$; (f) $\sigma=1.2, b_{1}=0.1, b_{2}=60, \beta=[0,1]$.
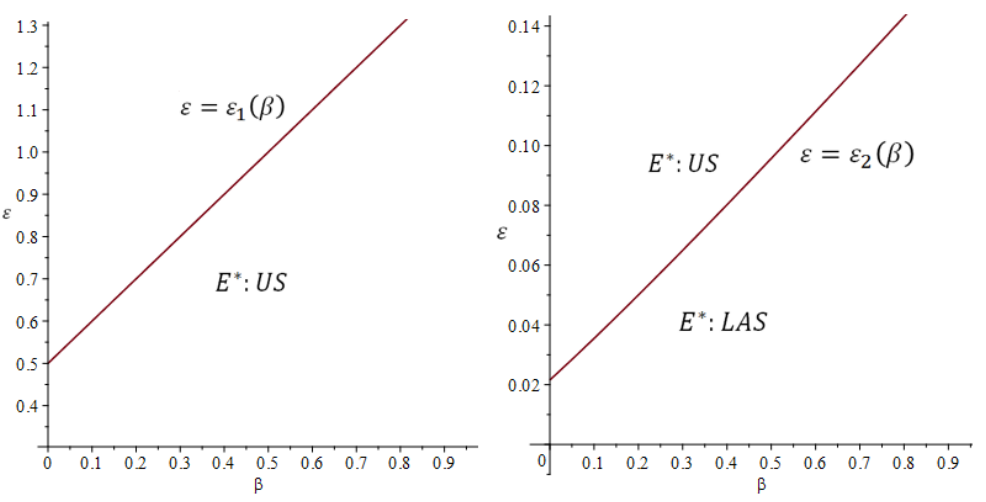

(c)


(d) 

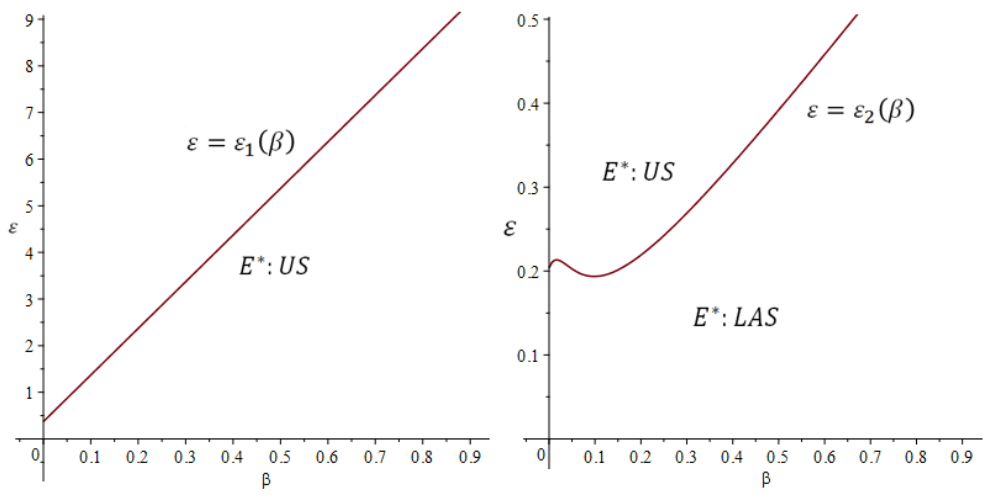

(e)


(f)

Gambar 3. Wilayah Keberadaan dan Stabilitas Lokal $E^{*}$ di Bidang $\beta-\varepsilon$ : (c), (d), (e) dan (f) Semuanya Untuk Kasus dimana $\sigma>b_{1}$

Namun, jika $\sigma>b_{1}$ maka $\varepsilon_{2}(\beta)<\varepsilon_{1}(\beta)$. Karenanya, ada empat situasi seperti yang ditunjukkan pada Gambar 3 (c) - (f). Dari ungkapan $a_{1} a_{2}-a_{3}$ dapat disimpulkan bahwa $E^{*}$ tidak stabil jika titik $(\beta, \varepsilon)$ terletak di antara kedua kurva $\varepsilon=\varepsilon_{1}(\beta)$ dan $\varepsilon=\varepsilon_{2}(\beta)$ sedangkan stabil jika titik $(\beta, \varepsilon)$ berada di bawah kurva $\varepsilon=\varepsilon_{2}(\beta)$. Dari empat situasi tersebut kita tahu bahwa untuk $\beta$ yang diberikan, jika $E^{*}$ eksis maka $E^{*}$ dapat kehilangan stabilitasnya dengan peningkatan $\varepsilon$. Namun, ketika $\varepsilon$ adalah tetap, perubahan stabilitas $E^{*}$ terhadap $\beta$ berbeda dalam empat situasi.

Pada Gambar 3 (c), jika $\varepsilon \leq \varepsilon_{2}(0), E^{*}$ selalu stabil secara lokal asimtotik, yang berarti bahwa stabilitas $E^{*}$ tidak akan berubah; ketika $\varepsilon>\varepsilon_{2}(0)$, stabilitasnya dapat berubah dari tidak stabil menjadi stabil secara asimtotik lokal dengan peningkatan $\beta$.

Pada Gambar 3 (d), ada tiga jenis perubahan stabilitas $E^{*}$. (i) Ketika $\varepsilon$ kurang dari minimum fungsi $\varepsilon_{2}(\beta), E^{*}$ selalu stabil secara lokal asimtotik. (ii) Ketika $\varepsilon$ berada di antara $\varepsilon_{2}(0)$ dan minimum, stabilitas berubah dari stabil menjadi tidak stabil menjadi stabil, yaitu, perubahan stabilitas terjadi saat $\beta$ meningkat. (iii) Ketika $\varepsilon>\varepsilon_{2}(0)$, stabilitas bisa hilang dengan peningkatan $\beta$.

Dalam Gambar 3 (e), ada empat kasus tentang perubahan stabilitas $E^{*}$, dua di antaranya akan memiliki perubahan stabilitas. (i) Ketika $\varepsilon$ kurang dari minimum fungsi $\varepsilon_{2}(\beta), E^{*}$ selalu stabil secara lokal asimtotik. (ii) Ketika $\varepsilon$ berada di antara $\varepsilon_{2}(0)$ dan minimum, stabilitas berubah dari stabil menjadi tidak stabil menjadi stabil. (iii) Jika $\varepsilon$ berada di antara $\varepsilon_{2}(0)$ dan nilai maksimal lokal, stabilitas berubah dari tidak stabil menjadi stabil menjadi tidak stabil menjadi stabil. (iv) Jika $\varepsilon$ lebih besar dari nilai maksimal lokal, stabilitas berubah dari tidak stabil menjadi stabil. 
Pada Gambar 3(f), ada juga empat kemungkinan, yang berbeda dari yang ada pada Gambar 3(e). perubahan stabilitas hanya dapat terjadi dalam satu kasus. (i) Ketika $\varepsilon \leq \varepsilon_{2}(0)$, $E^{*}$ selalu stabil secara lokal asimtotik. (ii) Jika $\varepsilon$ berada di antara $\varepsilon_{2}(0)$ dan nilai minimal lokal, stabilitas berubah dari tidak stabil menjadi stabil. (iii) Jika $\varepsilon$ berada di antara dua nilai ekstrim, stabilitas berubah dari tidak stabil menjadi stabil menjadi tidak stabil menjadi stabil. (iv) Jika $\varepsilon$ lebih besar dari nilai maksimal lokal, stabilitas berubah dari tidak stabil menjadi stabil.

Pernyataan di atas tentang perubahan stabilitas kesetimbangan positif $E^{*}$ dengan $\beta$ menunjukkan kompleksitas pengaruh kanibalisme terhadap dinamika model (4). Ini juga menunjukkan bahwa, untuk $\varepsilon$ yang diberikan, kesetimbangan positif $E^{*}$ stabil untuk $\beta$ yang cukup besar setiap kali ada.

\subsection{Simulasi Numerik}

Pada subbab ini akan dibahas tentang simulasi dari persamaan (4) dengan nilai parameter yang diberikan. Menggunakan nilai parameter $\beta$ dan $\varepsilon$ yang berbeda dan dilakukan pada empat syarat awal. Kemudian simulasikan maka didapatkan grafik perilaku dari sistem tersebut. Pada nilai parameter $\sigma=4.4, b_{1}=2.5, b_{2}=1.5, \beta=5.2, \varepsilon=1.25$ dan syarat awal $(12.5,0.45,11)$ ditandai dengan warna merah serta $(13,0.5,7)$ ditandai dengan warna biru sehinggga didapatkan grafik dengan memberikan titik kesetimbangan $E^{*}$ yang ditandai dengan warna hijau sebagai berikut:

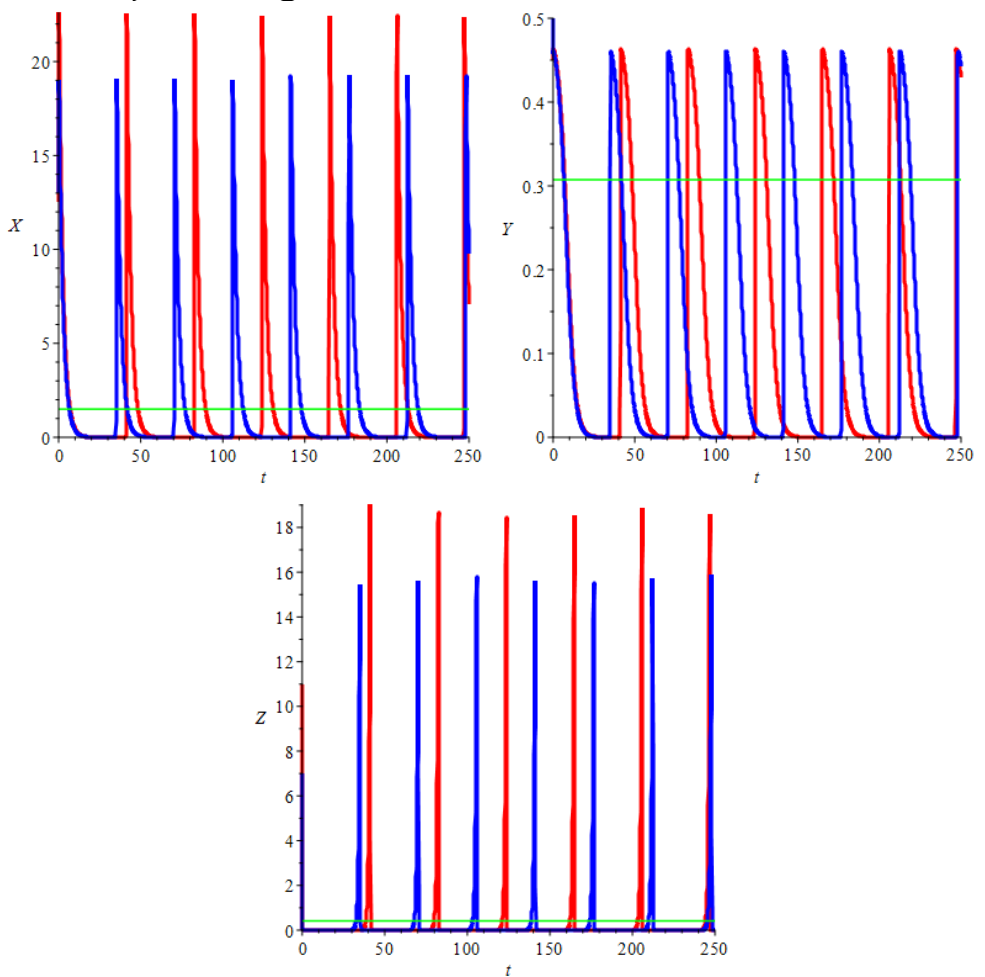

Gambar 4. Limit cycle Stabil Pada Solusi Sistem (4) 
Kemudian plot tiga dimensi diberikan sebagai berikut:

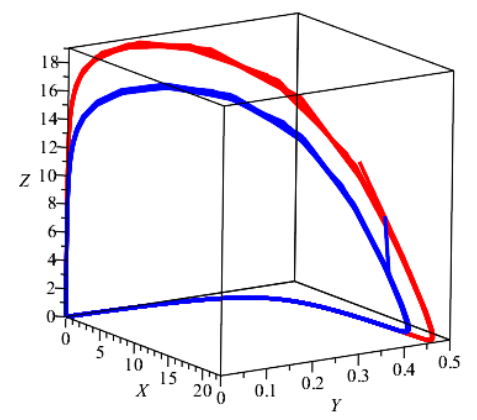

Gambar 5. Potret Fase Solusi Sistem (4) dengan Limit Cycle Stabil

Pada Gambar 4 dan 5, menggambarkan komponen dari solusi sistem (4) dengan $\sigma=$ $4.4, b_{1}=2.5, b_{2}=1.5, \beta=5.2$, dan $\varepsilon=1.25$. Dimana amplitudonya masing-masing naik dan turun, serta mengalami osilasi yang menjauhi dan tidak mencapai titik kesetimbangan sehingga gambar 4 dan 5 merupakan perilaku dari model predator-prey yang tidak stabil. Orbit 3-dimensi yang sesuai ditampilkan pada gambar 5. Pada kedua gambar, warna yang sama menunjukkan nilai awal yang sama. Pada hasil simulasi tersebut menunjukkan bahwa ada siklus batas (limit cycle) yang stabil untuk sistem (4) artinya dua nilai kondisi awal tersebut masing-masing berjalan mendekati siklus batas dan bifurkasi hopf bersifat super kritis.

Kemudian pada gambar 6 dan 7 nilai parameternya yaitu $\sigma=4.4, b_{1}=2.5, b_{2}=$ $1.5, \beta=0.025, \varepsilon=0.02$ dan syarat awal $(0.25,1.32,1.33)$ ditandai dengan warna merah serta $(0.25,1.32,2.83)$ ditandai dengan warna biru sehinggga didapatkan grafik dengan memberikan titik kesetimbangan $E^{*}$ yang ditandai dengan warna hijau sebagai berikut:
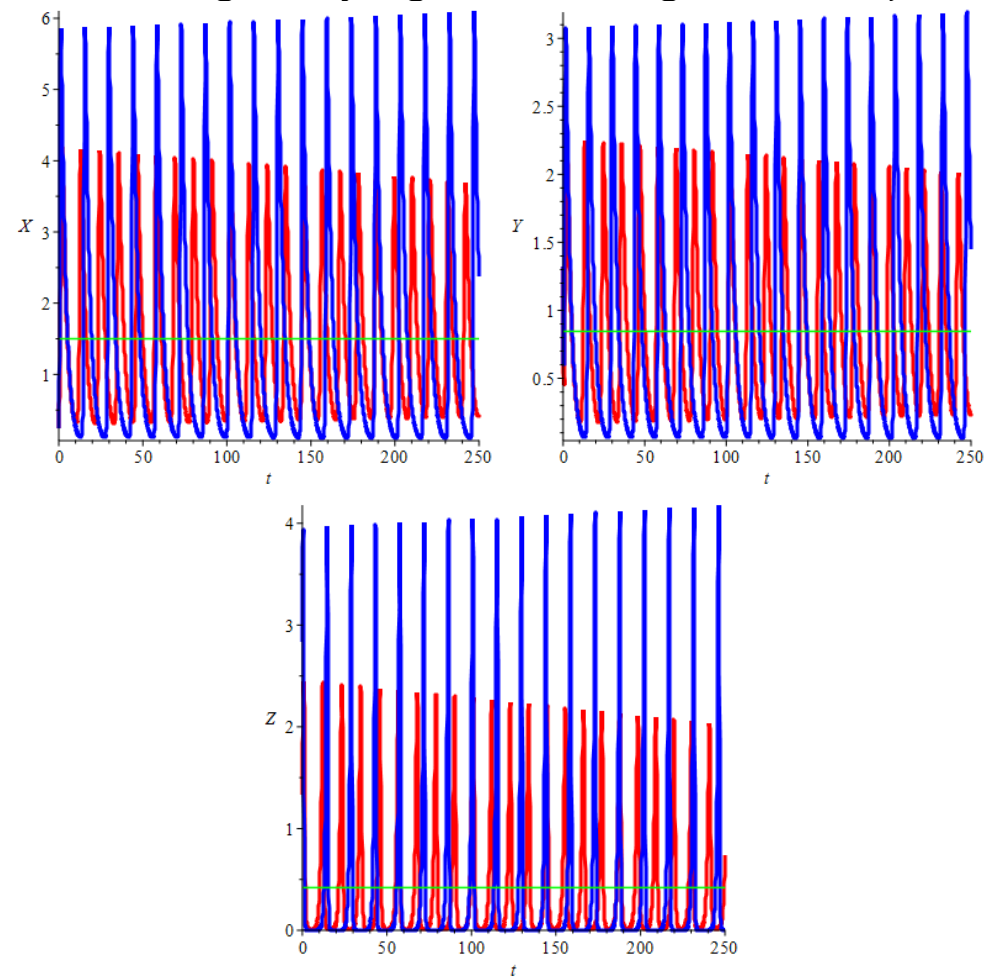

Gambar 6. Limit Cycle Tidak Stabil Pada Solusi Sistem (4) 
Kemudian plot tiga dimensi diberikan sebagai berikut:

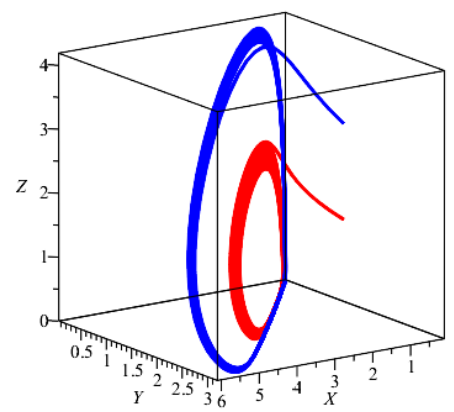

Gambar 7. Potret Fase Solusi Sistem (4) dengan Limit Cycle Tidak Stabil

Pada Gambar 6 dan 7, menggambarkan komponen dari solusi sistem (4) dengan $\sigma=$ $4.4, b_{1}=2.5, b_{2}=1.5, \beta=0.025$, dan $\varepsilon=0.02$. Dimana amplitudonya masing-masing naik dan turun, serta mengalami osilasi yang mendekati dan mencapai titik kesetimbangan sehingga gambar 6 dan 7 merupakan perilaku dari model predator-prey yang stabil. Orbit 3-dimensi yang sesuai ditampilkan pada gambar 7. Pada kedua gambar, warna yang sama menunjukkan nilai awal yang sama. Pada hasil simulasi tersebut menunjukkan bahwa ada siklus batas (limit cycle) yang tidak stabil untuk sistem (4) artinya dua nilai kondisi awal tersebut masing-masing berjalan menjauhi siklus batas dan bifurkasi hopf bersifat subkritis.

Kemudian pada gambar 8 dan 9 nilai parameternya yaitu $\sigma=4.4, b_{1}=2.5, b_{2}=$ $1.5, \beta=5.2, \varepsilon=0.02$ dan kondisi awal $P_{1}=(0.25,1.32,1.33)$ sehingga didapatkan grafik dengan memberikan titik kesetimbangan $E^{*}$ yang ditandai dengan warna hijau sebagai berikut:
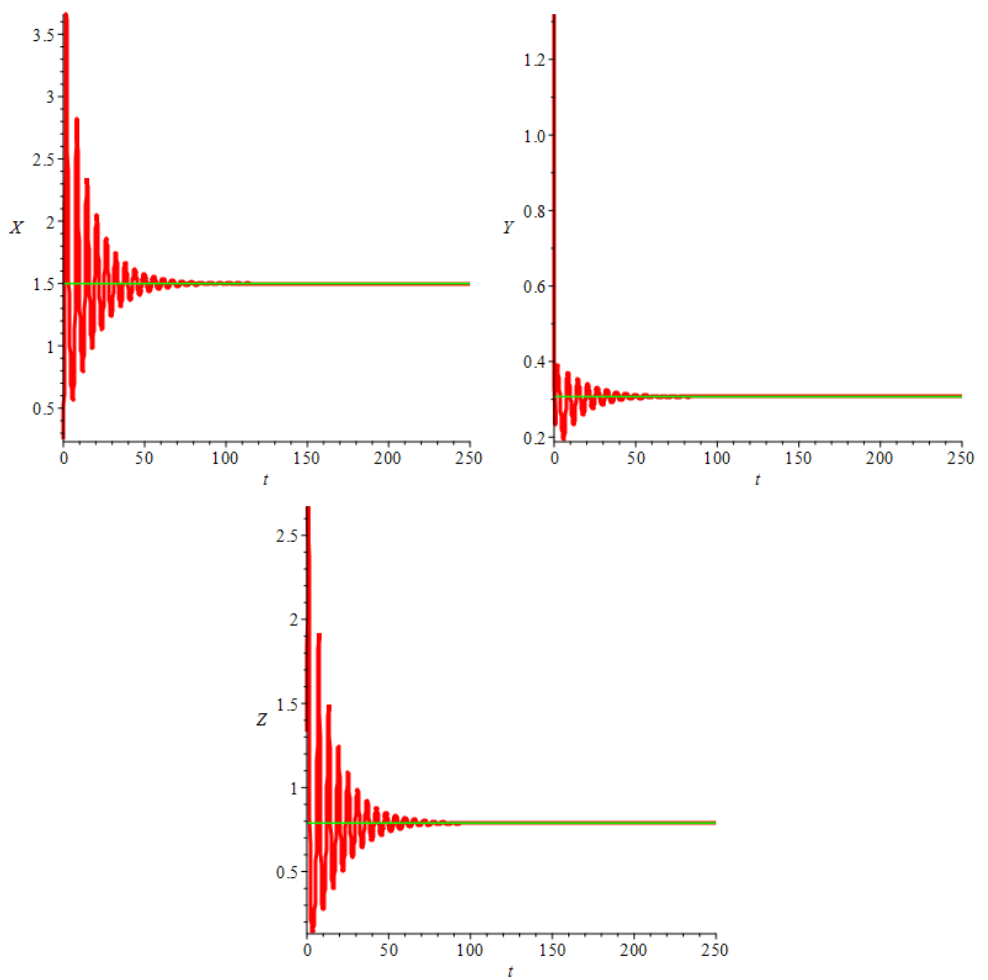

Gambar 8. Solusi Sistem (4) dengan Syarat Awal $P_{1}=(0.25,1.32,1.33)$

Kemudian dengan kondisi awal yang berbeda yaitu ketika $P_{2}=(x(0)=0.25, y(0)=$ $1.5, z(0)=1.7)$ didapatkan grafik dengan memberikan titik kesetimbangan $E^{*}$ sebagai berikut: 


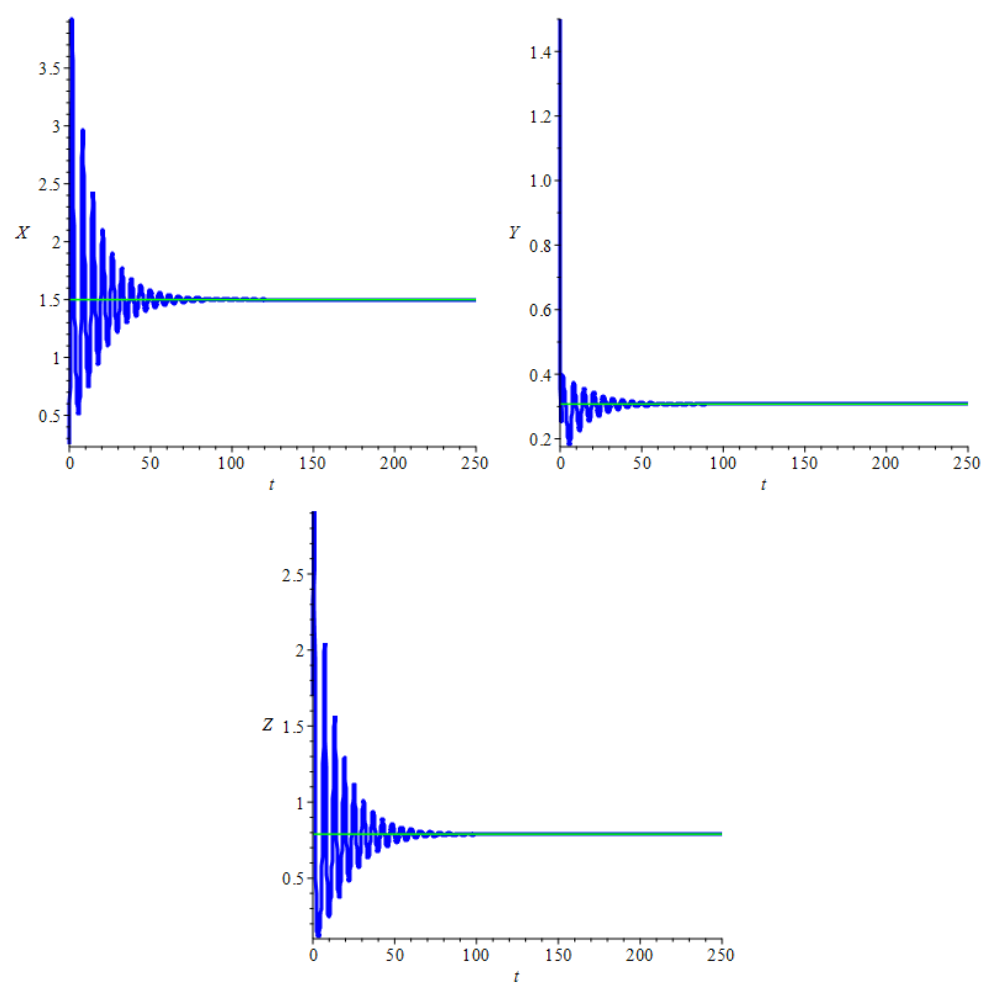

Gambar 9. Solusi Sistem (4) dengan Syarat Awal $P_{2}=(0.25,1.5,1.7)$

Gambar 8 dan 9 merupakan hasil simulasi numerik yang menunjukkan dinamika model predator-prey dengan faktor kanibalisme pada predator dengan dua syarat awal yang berbeda. Berdasarkan hasil simulasi, dengan syarat awal $P_{1}=(x(0)=0.25, y(0)=$ $1.32, z(0)=1.33) \quad$ dan $P_{2}=(x(0)=0.25, y(0)=1.5, z(0)=1.7)$ mengalami osilasi masing-masing naik dan turun pada waktu $t=0-50$. Pada akhirnya yaitu pada $t=100$ dan seterusnya, osilasi menuju ke titik kesetimbangan. Sehingga dapat dikatakan dengan nilai parameter dan kondisi tersebut yang mengikuti kondisi kestabilan titik kesetimbangan $E^{*}$ yaitu ketika $\sigma>b_{1}$ dan $\varepsilon<\varepsilon_{2}(\beta)$ stabil secara lokal asimtotik. Dapat dilihat bahwa hasil terbaik yaitu ketika jumlah populasi prey lebih besar dari pada jumlah populasi predator dan jumlah populasi predator remaja lebih besar dari pada jumlah populasi predator dewasa.

\section{KESIMPULAN}

Pada analisis dinamik model predator-prey tanpa kanibalisme, terdapat tiga titik kesetimbangan yaitu titik asal $O$ yang merupakan saddle, titik $E_{0}$ yang selalu tidak stabil dan titik $E^{*}$ yang stabil secara global asimtotik. Pada analisis dinamik dinamik model predatorprey dengan faktor kanibalisme pada predator, terdapat tiga titik kesetimbangan yaitu titik asal $O$ yang selalu tidak stabil, titik $E_{0}$ yang stabil secara lokal asimtotik dengan kondisi tertentu dan titik $E^{*}$ yang stabil secara lokal asimtotik dan global asimtotik dengan kondisi tertentu. Sensitivitas titik kesetimbangan pada parameter $\beta$ dan $\varepsilon$, diilustrasikan secara geometris untuk menghasilkan daerah yang sesuai pada bidang $\beta-\varepsilon$. Dapat dilihat bahwa hasil terbaik adalah untuk model predator-prey dengan faktor kanibalisme pada predator yang stabil secara lokal asimtotik yaitu ketika $\varepsilon$ lebih kecil dari fungsi minimum $\varepsilon_{2}(\beta)$ dan $\varepsilon \leq \varepsilon_{2}(0)$ pada titik $E^{*}$. Berdasarkan simulasi numerik dengan memberikan beberapa syarat awal, dapat disimpulkan bahwa terdapat perilaku model predator-prey dengan kanibalisme yang stabil dan tidak stabil serta terdapat siklus batas yang memungkinkan terjadinya bifurkasi hopf. 


\section{DAFTAR PUSTAKA}

[1] Olinick, Michael, Mathematical Modeling in The Social and Life Sciences, America: Wiley, 2014.

[2] Zill, D., Wright, W., \& Cullen, M., Differential Equations with Boundary Value Problems (8 ${ }^{\text {th }}$ ed.), New York: Cengage Learning, 2013.

[3] Waluya, S.B., Persamaan Diferensial, Yogyakarta: Graha Ilmu, 2006.

[4] Hariyanto, Persamaan Diferensial Biasa, Jakarta: Universitas Terbuka, 1992.

[5] Basheer, Aladeen,dkk. "Prey Cannibalism Alters The Dynamics of Holling-Tanner-Type Predator-Prey Models," Nonllinier Dyn Springer and Business Media Dordrecht, 2016.

[6] Basheer, Aladeen, Jingjing Lyu, dkk. "The Destabilizing Effect of Cannibalism in A Spatially Explicit Three-Species Age Structured Predator-Prey Model," Wiley Hindawi, 2017.

[7] Biswas, Santosh, dkk. "A Model Based Theoretical Study on Cannibalistic Prey-Predator System with Disease in Both Populations," Differ Equ Dyn Syst, 2014.

[8] Biswas, Santosh dkk. "Cannibalistic Predator-Prey Model with Disease in Predator- A Delay Model," International Journal of Bifurcation and Chaos, Vol 25(10), 2015.

[9] Zhang, Fengqin, Yuming Chen, and Jianquan Li, "Dynamical Analysis of A Stage-Structured PredatorPrey Model with Cannibalism," Mathematical Biosciences, 307, 2019.

[10] Boyce, W.E., \& Diprima, R. C., Elementery Differential Equations and Boundary Value Problem (7th ed.), New York: John Wiley \& Sons, 2001.

[11] Ndii, Meksianis Zadrak, Pemodelan Matematika Dinamika Populasi Dan Penyebaran Penyakit, Yogyakarta: DEEPUBLISH, 2018.

[12] DiStefano III, J. J., Stubberud, A. R., \& Williams, I. J., Feedback and Control System (Second Ed.), United States: McGraw-Hill Education,1990.

[13] Lina, Oktavia L., "Penggunaan Metode Lyapunov untuk Menguji Kestabilan Sistem Linier," Jurnal Matematika UNAND,Vol 3(2), 2014.

[14] Sundari, Reni \& Erna Apriliani, “Konstruksi Fungsi Lyapunov untuk Menentuan Kestabilan," Jurnal Sains dan Seni ITS, Vol 6(1), 2017.

[15] Strogatz, Steven H., Nonlinear Dynamics and Chaos With Applications to Physics, Biology, Chemistry, and Engineering, New York: Perseus Books Group, 1994. 